\title{
Reversal of Secondary Hyperparathyroidism by Cimetidine in Chronically Uremic Dogs
}

\author{
Allan I. Jacob, Janet M. Canterbury, George Gavellas, Phillip W. Lambert, \\ JACQUES J. BouRgoIGNIE, Department of Medicine, University of Miami School \\ of Medicine, Miami, Florida 33101; Case Western Reserve University, \\ Veterans Administration Hospital Cleveland, Ohio 44106
}

A B S T R A C T Chronic cimetidine therapy has been shown to suppress circulating concentrations of immunoreactive parathyroid hormone (iPTH) in hemodialysis patients. To evaluate the long-term metabolic effects of cimetidine treatment, we studied seven chronically uremic dogs for $20 \mathrm{wk}$. The dogs were studied under metabolic conditions before, during, and after cimetidine therapy. iPTH fell progressively in the five treated dogs from $536 \pm 70 \mu \mathrm{leq} / \mathrm{ml}$ (mean $\pm \mathrm{SE}$ ) $(\mathrm{nl}<100 \mu \mathrm{leq} / \mathrm{ml}$ ) before treatment to $291 \pm 25 \mu \mathrm{leq} / \mathrm{ml}$ at $12 \mathrm{wk}(P<0.001)$ and $157 \pm 32 \mu \mathrm{leq} / \mathrm{ml}$ at $20 \mathrm{wk}$ $(P<0.001)$. The control dogs showed no consistent change in iPTH. The fall in IPTH was not associated with a change in serum ionized calcium. However, serum phosphorus decreased from $5.7 \pm 0.9 \mathrm{mg} / \mathrm{dl}$ to $3.4 \pm 0.2 \mathrm{mg} / \mathrm{dl}$ by the 20 th wk $(P<0.05)$. By contrast, the serum concentration of 1,25-dihydroxycholecalciferol increased in all treated dogs from $33.4 \pm 4.3$ $\mathrm{pg} / \mathrm{ml}$ to $51.8 \pm 2.4 \mathrm{pg} / \mathrm{ml}$ during treatment $(P<0.01)$. Calcium balance was negative in all seven dogs before cimetidine $(-347 \pm 84 \mathrm{mg} / 72 \mathrm{~h})$ and remained so in the control dogs; it became positive in the five treated dogs after $12 \mathrm{wk}(1,141 \pm 409 \mathrm{mg} / 72 \mathrm{~h})(P<0.05)$. Phosphorus balance, 24-h fractional phosphate excretion, and creatinine clearance remained unchanged. Pooled samples of serum obtained during the control and 20th wk of therapy were fractionated by gel filtration and the eluates assayed for immunoreactivity. The decrease in iPTH was associated with a decrease in all the immunoreactive species, indicating suppression of parathyroid gland secretion.

These observations indicate that cimetidine suppressed circulating concentration of biologically active

This work presented in part at the Thirty-seventh Annual Meeting of the American Federation for Clinical Research, Washington, D. C., May 1980.

Address reprint requests to $\mathrm{Dr}$. Jacob at Division of $\mathrm{Ne}-$ phrology (R-126), P. O. 016960, Miami, Fla. 33101.

Received for publication 29 September 1980 and in revised form 18 February 1981. parathyroid hormone. A probable net decrease in the loss of phosphorus from bone to blood ensued, resulting in a fall in serum phosphorus. This may have stimulated synthesis of 1,25-dihydroxycholecalciferol and led to a positive calcium balance, thereby maintaining the serum ionized calcium concentration. The maintenance of phosphate balance, despite suppression of iPTH by cimetidine, indicates that factors other than hyperparathyroidism relate to phosphate homeostasis in chronically uremic dogs.

\section{INTRODUCTION}

Secondary hyperparathyroidism is a serious complication of chronic renal failure and has been associated with many aspects of the uremic syndrome $(1,2)$. For this reason, the prevention and treatment of uremic hyperparathyroidism (HPTH) ${ }^{1}$ remains an area of active investigation (3-5). We recently reported that cimetidine, a histamine $\mathrm{H}_{2}$ antagonist, decreased circulating concentrations of immunoreactive parathyroid hormone (iPTH) by $75 \%$ in a group of hemodialysis patients without associated changes in serum ionized calcium or phosphorus concentrations (6). After discontinuation of the drug, hyperparathyroidism returned. This effect of cimetidine could be secondary to either a decrease in secretion of PTH or an acceleration of peripheral PTH metabolism. If less PTH was secreted, a decrease of serum calcium would have been expected to occur. The maintenance of eucalcemia in our patients suggested additional effects of cimetidine on calcium homeostasis.

The purpose of this study was to determine in chronically uremic dogs the detailed effects of pro-

\footnotetext{
${ }^{1}$ Abbreviations used in this paper: HPTH, hyperparathyroidism; iPTH, immunoreactive parathyroid hormone; $25(\mathrm{OH}) \mathrm{D}, 25$-hydroxycholecalciferol; $24,25(\mathrm{OH})_{2} \mathrm{D}, 24,25$ dihydroxycholecalciferol, $1,25(\mathrm{OH})_{2} \mathrm{D}, 1,25$-dihydroxycholecalciferol.
} 
longed cimetidine therapy on calcium and phosphate homeostasis, the spectrum of immunoreactive species of circulating PTH, and the concentration of circulating metabolites of vitamin $\mathrm{D}$.

\section{METHODS}

Experimental design. Seven adult female mongrel dogs weighing $15-18 \mathrm{~kg}$ were studied. Renal insufficiency was induced by ligation of the majority of the branches of the renal artery on one side followed, 2 wk later, by contralateral nephrectomy (7). After a period of stabilization varying from 12 to $18 \mathrm{mo}$, the dogs were studied under metabolic conditions described previously (8). In brief, after a period of adjustment in metabolic cages, control observation was made for 1 wk. Five dogs then received cimetidine in tablet form for $20 \mathrm{wk}$; the tablets were placed in the pharynx and swallowing was assured by observation. Three dogs received $300 \mathrm{mg}$ daily and two received $300 \mathrm{mg}$ twice daily. Two dogs served as controls and did not receive cimetidine. All dogs remained in metabolic cages for four additional consecutive weeks during which the experimental observations were made. The dogs were then removed from the cages and placed in runs for $7 \mathrm{wk}$. The same amount of diet was offered daily. The dogs were then returned to cages for further balance studies on the 12th wk. Cimetidine treatment was then continued for a total of $20 \mathrm{wk}$. $14 \mathrm{wk}$ after discontinuation of cimetidine the dogs were restudied in the balance cages.

The dogs ate Purina high-protein dog meal (Ralston Purina Co., St. Louis, Mo.) containing $1.6 \mathrm{~g}$ calcium, $0.950 \mathrm{~g}$ phosphorus, $0.150 \mathrm{~g}$ magnesium, and $176 \mathrm{U}$ vitamin $\mathrm{D} / 100 \mathrm{~g}$ diet. Analysis of the diet confirmed the labeled value for the diet's calcium, phosphorus, and magnesium content within $10 \%$. $300 \mathrm{~g}$ of the diet were offered daily while the dogs were in the cages. The amount of diet actually consumed was determined by the difference of food available to the dogs and the amount remaining after each day. The partially exposed position of the feeding pan in the cage door prevented any scattering of the diet thereby insuring accurate measurements of intake. Blood samples were obtained anaerobically three times a week during balance studies at $10 \mathrm{a} . \mathrm{m}$. from an anterior limb vein before changing the food. Samples were analyzed for ionized calcium, phosphorus, iPTH, and creatinine. Blood samples were also obtained during the 20th wk of therapy and 7, 14, and 20-30 wk after discontinuation of cimetidine. During the 20th wk, bovine PTH (Inolex, Inc. Chicago, Ill.) was infused $(4 \mathrm{U} / \mathrm{kg}$ per $\mathrm{h}$ for $3 \mathrm{~h})$ and the calcemic response measured. Details of this protocol have been previously reported (5). Plasma samples were obtained for measurement of 25-hydroxycholecalciferol (25 [OH]D), 24,25 -dihydroxycholecalciferol $\left(24,25[\mathrm{OH}]_{2} \mathrm{D}\right)$ and $1,25-$ dihydroxycholecalciferol $\left(1,25[\mathrm{OH}]_{2} \mathrm{D}\right)$ during the control week and the 20th wk of cimetidine therapy.

\section{Analytical methods}

Formal 72-h metabolic balances were performed during the control, 1st, 2nd, 3rd, 4th, and 12th wk of treatment and $14 \mathrm{wk}$ after discontinuation of treatment. 24-h urines were collected during the balance study and analyzed for calcium, phosphorus, and creatinine. Carmine red dye was given via orogastric tube on Mondays and Thursdays and all stool passed between the appearance of the marker was collected. The dye marker appeared from 24 to $48 \mathrm{~h}$ after administration. Collection of all stools between markers insured an accurate fecal collection representative of the $72 \mathrm{~h}$ of food intake. Stool was prepared for analysis as described previously (8).
Total calcium concentration was measured in all samples by atomic absorption (Perkin-Elmer Corp., Instrument Div., Norwalk., Conn, model 107). Phosphorus and creatinine were measured by AutoAnalyzer and ionized calcium was measured with a selective ion flow-through electrode (Orion Research Inc., Cambridge, Mass., model 5520). Serum iPTH was assayed by methods previously described in great detail (9-11). Antiserum CH-71 at a dilution of 1:125,000 was used, which crossreacts with intact hormone as well as $\mathrm{NH2}$ - and $\mathrm{COOH}$-terminal fragments. Each sample was assayed in duplicate at two widely differing concentrations. The coefficient of variation of replicate samples was $9 \%$. PTH levels are reported in arbitrary units (microliter equivalents per milliliter) relating the potency of the test serum to that of a standard uremic HPTH standard.

Serum collected from the five cimetidine-treated dogs during the control week and 20th wk of therapy was pooled, concentrated, and chromatographed on a Bio-Gel P-10 column (Bio-Rad Laboratories, Richmond, Calif.) to separate the different immunoreactive molecular species of circulating PTH. These methods have been described previously in great detail (10).

Plasma $25(\mathrm{OH}) \mathrm{D}, 24,25(\mathrm{OH})_{2} \mathrm{D}$, and $1,25(\mathrm{OH})_{2} \mathrm{D}$ were measured by methodology previously reported $(12,13)$. Following sequential methanol: methylene chloride extraction, Sephadex LH-20 chromatography, and normal phase gradient high-performance liquid chromatography of the plasma samples, individual vitamin $\mathrm{D}$ metabolites were quantitated by radioligand binding assays. The $25(\mathrm{OH}) \mathrm{D}$ and $24,25(\mathrm{OH})_{2} \mathrm{D}$ assays using a normal rat plasma binding protein had limits of detection of $0.1 \mathrm{ng}$ per assay tube. The ligand binding assay for $1,25(\mathrm{OH})_{2} \mathrm{D}$ employs an intestinal mucosal cytosol receptor from rachitic chicks, a Tris- $\mathrm{HCl}, \mathrm{KCl}$, thioglycerolglycerol buffer system and dextran-charcoal-human plasma separation of receptor bound from free $1,25(\mathrm{OH})_{2} \mathrm{D}$. The lower limit of detection was $2 \mathrm{pg}$ per assay tube. The coefficient of variation of replicate samples for the 25(OH)D and $24,25(\mathrm{OH})_{2} \mathrm{D}$ assays is $8 \%$ and the $1,25(\mathrm{OH})_{2} \mathrm{D}$ assay $5 \%$.

The data were analyzed by the Prophet computer system developed and sponsored by the Biological Handling Program, Division of Research Resources, National Institutes of Health. Statistical analyses used two-way analysis of variance and Dunnet's multiple range test and are expressed as mean \pm SEM.

\section{RESULTS}

The values for ionized calcium, phosphorus and iPTH are presented in Table $I$. The creatinine clearance ranged from 5.5 to $16.1 \mathrm{ml} / \mathrm{min}$. Fasting ionized calcium was within the range seen for normal dogs ingesting a similar diet in our laboratory (14). Serum phosphorus ranged from 3.8 to $9.0 \mathrm{mg} / \mathrm{dl}$.

All dogs were hyperparathyroid before treatment (Table I). The mean iPTH value was $561 \pm 54 \mu \mathrm{leq} / \mathrm{ml}$ (normal, $<100 \mu \mathrm{leq} / \mathrm{ml}$ ) for all seven dogs. HPTH is a consistent finding in chronically uremic dogs $(4,5,8,9$, $14,15)$. After 1 wk of cimetidine administration, the iPTH values fell in all five treated dogs by $12 \pm 4$ $\mu \mathrm{leq} / \mathrm{ml}(P<0.05)$. The fall in iPTH after cimetidine was progressive and by the 20th wk of therapy iPTH had fallen to $155 \pm 30 \mu \mathrm{leq} / \mathrm{ml}(P<0.01)$ (not shown in table). In two dogs iPTH values fell to within the normal range. In contrast, iPTH values in the two un- 
TABLE I

Ionized Calcium, Phosphorus, IPTH, Creatinine Clearances, and Metabolic Balances in Five Dogs Receiving Cimetidine and Two Control Dogs

\begin{tabular}{|c|c|c|c|c|c|c|c|c|c|c|c|c|c|c|c|}
\hline \multirow[b]{2}{*}{ Treatment } & \multirow[b]{2}{*}{ Week } & \multirow[b]{2}{*}{$\mathrm{C}_{\mathrm{CR}}$} & \multirow[b]{2}{*}{ iPTH } & \multirow[b]{2}{*}{$\mathrm{Ca}++$} & \multirow[b]{2}{*}{$\mathbf{P}$} & \multicolumn{5}{|c|}{ Calcium ( $g / 72 \mathrm{~h}$ ) } & \multicolumn{5}{|c|}{ Phosphorus (g/72 h) } \\
\hline & & & & & & Intake & Feces & $\begin{array}{l}\text { Net ab- } \\
\text { sorption }\end{array}$ & Urine & Balance & Intake & Feces & $\begin{array}{l}\text { Net ab- } \\
\text { sorption }\end{array}$ & Urine & Balance \\
\hline & & $m l / m i n$ & $\mu l e q / m l$ & meq/liter & $m g / d l$ & & & & & & & & & & \\
\hline \multicolumn{16}{|l|}{ Control } \\
\hline \multirow[t]{6}{*}{1} & C & 16.1 & 518 & 2.59 & 3.8 & 10.76 & 11.04 & -0.280 & 0.054 & -0.334 & 6.39 & 5.37 & +1.020 & 1.26 & -0.240 \\
\hline & 1 & 16.1 & 518 & 2.68 & 3.9 & 10.96 & 11.80 & -0.840 & 0.072 & -0.912 & 6.51 & 6.56 & -0.050 & 1.16 & -1.21 \\
\hline & 2 & 17.4 & 523 & 2.69 & 3.5 & 9.29 & 11.52 & -2.230 & 0.077 & -2.307 & 5.52 & 5.52 & +0.000 & 1.42 & -1.42 \\
\hline & 3 & 20.9 & 525 & 2.66 & 3.3 & 12.64 & 12.60 & +0.040 & 0.074 & -0.034 & 7.51 & 6.06 & +1.450 & 1.40 & +0.050 \\
\hline & 4 & 16.6 & 523 & 2.63 & 2.4 & 8.00 & 8.80 & -0.800 & 0.078 & -0.878 & 4.75 & 5.58 & -0.830 & 1.20 & -2.03 \\
\hline & 12 & 12.1 & 555 & 2.72 & 3.4 & 7.44 & 8.49 & -1.050 & 0.020 & -1.070 & 4.41 & 5.28 & -0.870 & 0.938 & -1.81 \\
\hline \multirow[t]{6}{*}{2} & $\mathrm{C}$ & 7.1 & 732 & 2.63 & 5.9 & 11.8 & 12.0 & -0.200 & 0.059 & -0.259 & 7.01 & 5.76 & +1.340 & 0.99 & +0.260 \\
\hline & 1 & 6.6 & 733 & 2.66 & 5.6 & 7.39 & 7.44 & -0.050 & 0.043 & -0.093 & 4.38 & 3.04 & +1.340 & 1.02 & +0.320 \\
\hline & 2 & 6.2 & 723 & 2.63 & 5.0 & 9.10 & 9.20 & -0.100 & 0.028 & -0.128 & 5.41 & 4.12 & +1.290 & 0.882 & +0.408 \\
\hline & 3 & 6.7 & 723 & 2.67 & 5.4 & 12.21 & 12.96 & -0.750 & 0.048 & -0.798 & 7.25 & 6.24 & +1.010 & 1.00 & +0.010 \\
\hline & 4 & 6.6 & 718 & 2.65 & 4.9 & 11.5 & 11.84 & -0.340 & 0.033 & -0.373 & 6.84 & 6.72 & +0.120 & 0.883 & -0.763 \\
\hline & 12 & 5.9 & 425 & 2.66 & 6.6 & 12.80 & 12.96 & -0.160 & 0.030 & -0.190 & 7.60 & 7.36 & +0.240 & 1.54 & -1.30 \\
\hline \multicolumn{16}{|l|}{ Cimetidine } \\
\hline \multirow[t]{7}{*}{1} & C & 8.5 & 365 & 2.63 & 5.9 & 14.4 & 15.0 & -0.600 & 0.190 & -0.79 & 8.55 & 8.96 & -0.410 & 1.44 & -1.850 \\
\hline & 1 & 9.9 & 358 & 2.66 & 5.8 & 14.4 & 15.6 & -1.200 & 0.230 & -1.43 & 8.55 & 7.44 & +1.110 & 1.77 & -0.660 \\
\hline & 2 & 10.8 & 335 & 2.71 & 5.1 & 14.4 & 14.3 & -0.100 & 0.190 & -0.090 & 8.55 & 10.3 & -1.750 & 1.75 & -3.500 \\
\hline & 3 & 9.4 & 297 & 2.73 & 4.5 & 14.4 & 15.3 & -0.900 & 0.130 & -1.03 & 8.55 & 8.0 & +0.550 & 1.33 & -0.780 \\
\hline & 4 & 11.3 & 280 & 2.72 & 4.6 & 14.4 & 15.3 & -0.900 & 0.170 & -1.07 & 8.55 & 9.12 & -0.570 & 1.66 & -2.230 \\
\hline & 12 & 11.4 & 218 & 2.71 & 4.5 & 7.20 & 4.71 & +2.490 & 0.041 & +2.45 & 4.28 & 2.70 & +1.580 & 1.22 & +0.360 \\
\hline & 14 post & 14.2 & 210 & 2.78 & 5.0 & 9.60 & 10.08 & -0.480 & 0.108 & -0.588 & 5.70 & 5.40 & +0.300 & 1.312 & -1.012 \\
\hline \multirow[t]{7}{*}{2} & C & 15.1 & 630 & 2.58 & 4.0 & 10.3 & 10.6 & -0.300 & 0.011 & -0.311 & 6.14 & 4.96 & +1.180 & 0.91 & +0.270 \\
\hline & 1 & 17.5 & 607 & 2.61 & 3.8 & 8.0 & 9.9 & -1.900 & 0.025 & -1.925 & 4.77 & 4.74 & +0.030 & 1.29 & -1.260 \\
\hline & 2 & 19.9 & 565 & 2.59 & 3.9 & 10.96 & 10.34 & +0.620 & 0.067 & +0.553 & 6.51 & 5.10 & +1.410 & 1.08 & +0.330 \\
\hline & 3 & 18.8 & 478 & 2.59 & 3.6 & 14.4 & 14.4 & 0.000 & 0.049 & -0.049 & 8.55 & 6.35 & +2.200 & 1.33 & +0.870 \\
\hline & 4 & 19.5 & 500 & 2.59 & 3.9 & 13.7 & 12.4 & +1.300 & 0.048 & +1.252 & 8.12 & 5.34 & +2.780 & 1.12 & +1.66 \\
\hline & 12 & 17.6 & 307 & 2.70 & 4.2 & 8.89 & 8.29 & +0.600 & 0.018 & +0.582 & 5.28 & 4.96 & +0.320 & 0.899 & -0.579 \\
\hline & 14 post & 14.0 & 98 & 2.63 & 4.3 & 7.76 & 7.28 & +0.480 & 0.006 & +0.474 & 4.61 & 3.52 & +1.090 & 0.586 & +0.504 \\
\hline \multirow[t]{7}{*}{3} & C & 5.5 & 735 & 2.63 & 9.0 & 11.6 & 11.9 & -0.300 & 0.065 & -0.365 & 6.9 & 7.32 & -0.420 & 1.48 & -1.90 \\
\hline & 1 & 6.9 & 712 & 2.78 & 7.5 & 3.2 & 3.2 & 0.000 & 0.047 & -0.047 & 1.90 & 1.30 & +0.600 & 1.37 & -0.770 \\
\hline & 2 & 7.7 & 670 & 2.77 & 7.1 & 14.4 & 15.8 & -1.400 & 0.123 & -1.523 & 8.55 & 10.26 & -1.710 & 1.77 & -3.48 \\
\hline & 3 & 7.0 & 557 & 2.76 & 6.3 & 14.4 & 13.6 & +0.800 & 0.170 & +0.630 & 8.55 & 8.00 & +0.550 & 1.36 & -0.810 \\
\hline & 4 & 7.1 & 515 & 2.76 & 6.8 & 14.4 & 13.4 & +1.000 & 0.123 & +0.877 & 8.55 & 8.34 & +0.210 & 1.68 & -1.470 \\
\hline & 12 & 8.4 & 325 & 2.77 & 6.6 & 12.89 & 11.04 & +1.850 & 0.103 & +1.747 & 7.66 & 6.72 & +0.940 & 1.92 & -0.980 \\
\hline & 14 post & 9.0 & 192 & 2.80 & 6.5 & 11.3 & 11.29 & +0.010 & 0.102 & -0.094 & 6.75 & 5.94 & +0.810 & 1.798 & -0.988 \\
\hline 4 & $\mathrm{C}$ & 13.5 & 428 & 2.77 & 4.9 & 10.72 & 11.04 & -0.320 & 0.012 & -0.332 & 6.37 & 5.70 & +0.670 & 0.74 & -0.550 \\
\hline & 1 & 13.4 & 423 & 2.76 & 4.1 & 12.16 & 12.32 & -0.160 & 0.013 & -0.173 & 7.22 & 6.72 & +0.500 & 1.49 & -0.990 \\
\hline & 2 & 15.1 & 362 & 2.79 & 3.9 & 10.6 & 9.84 & +0.760 & 0.017 & +0.743 & 6.29 & 5.88 & +0.410 & 0.95 & -0.540 \\
\hline & 3 & 14.4 & 307 & 2.77 & 3.5 & 9.55 & 9.36 & +0.190 & 0.008 & +0.182 & 5.67 & 4.80 & +0.870 & 0.74 & +0.130 \\
\hline & 4 & 13.4 & 263 & 2.73 & 3.0 & 7.25 & 6.96 & +0.290 & 0.006 & +0.284 & 4.31 & 4.08 & +0.230 & 0.69 & -0.460 \\
\hline & 12 & 17.4 & 250 & 2.73 & 3.35 & 11.4 & 10.8 & +0.600 & 0.006 & +0.594 & 6.77 & 6.08 & +0.690 & 1.43 & -0.740 \\
\hline & 14 post & 15.7 & 395 & 2.65 & 5.4 & 8.12 & 6.5 & +1.620 & 0.016 & +1.624 & 5.42 & 4.40 & +1.020 & 1.32 & -0.300 \\
\hline 5 & C & 14.7 & 522 & 2.75 & 4.7 & 14.4 & 14.4 & 0.000 & 0.045 & -0.045 & 8.55 & 8.32 & +0.230 & 0.79 & -0.550 \\
\hline & 1 & 13.1 & 518 & 2.71 & 4.9 & 12.2 & 11.8 & +0.320 & 0.039 & +0.281 & 7.24 & 5.04 & +2.200 & 1.35 & +0.850 \\
\hline & 2 & 14.1 & 457 & 2.76 & 4.8 & 10.9 & 10.8 & +0.100 & 0.018 & +0.082 & 6.47 & 6.36 & +0.110 & 0.88 & -0.770 \\
\hline & 3 & 13.8 & 388 & 2.74 & 4.4 & 10.8 & 9.6 & +1.200 & 0.028 & +1.172 & 6.41 & 5.04 & +1.370 & 0.95 & +0.420 \\
\hline & 4 & 11.5 & 328 & 2.72 & 4.2 & 11.08 & 10.88 & +0.200 & 0.018 & +0.182 & 6.58 & 6.72 & -0.140 & 0.76 & -0.90 \\
\hline & 12 & 13.2 & 330 & 2.85 & 5.4 & 12.2 & 11.84 & +0.360 & 0.027 & +0.333 & 7.27 & 6.40 & +0.870 & 1.93 & -1.06 \\
\hline & 14 post & 12.1 & 363 & 2.61 & 5.7 & 7.02 & 7.38 & -0.360 & 0.013 & -0.373 & 4.77 & 5.0 & -0.230 & 1.12 & -1.35 \\
\hline
\end{tabular}

$\mathrm{C}_{\mathrm{CR}}$, creatinine clearances.

treated control uremic dogs remained constant except for an unexplained low value at $12 \mathrm{wk}$ in dog 2.

The decrease in iPTH as a percentage of control values is shown in Fig. 1 for the treated dogs. After 20 wk of cimetidine therapy iPTH values decreased by $75 \%$. When cimetidine was discontinued, iPTH re- turned to pretreatment levels in an unpredictable pattern. In two dogs, iPTH remained suppressed for $14 \mathrm{wk}$ after discontinuing the drug. iPTH returned to near base-line levels in all dogs by $20 \mathrm{wk}$.

Pooled samples of serum obtained during the control and 20th wk of therapy were fractionated by gel filtra- 


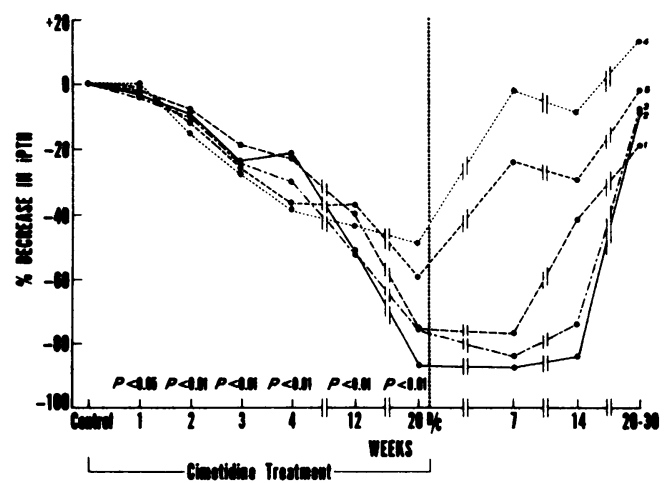

FIGURE 1 Cimetidine effects on iPTH in chronic uremia. Relative decrease in circulating PTH concentration in five uremic dogs before, during, and after cimetidine treatment. Each point represents the mean of three determinations. The numbers at each line correspond to the dogs in Table I.

tion and the eluates assayed for immunoreactivity (Fig. 2). It is evident that the decrease in iPTH was associated with a decrease in all the immunoreactive species. This indicates that the decrease in circulating iPTH during cimetidine therapy was secondary to less hormone secretion from the parathyroid glands rather than modifications in peripheral hormone metabolism.

Serum ionized calcium did not change throughout the study period (Fig. 3). However, there was a progres-
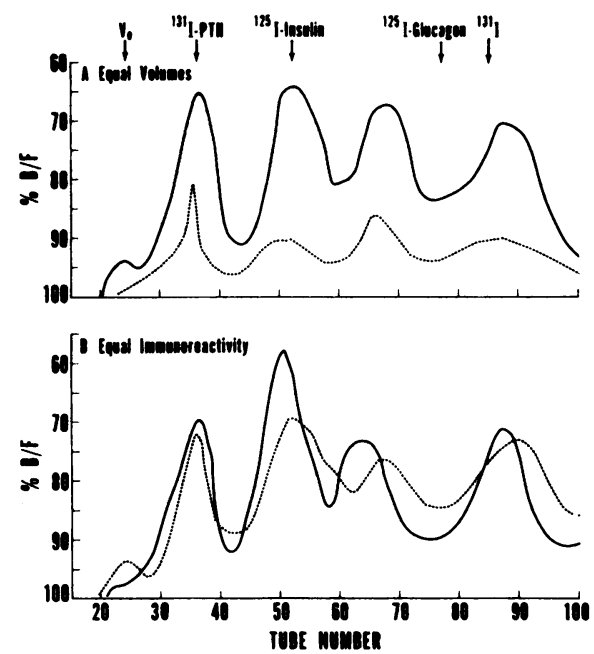

Figure 2 Elution profiles on P-10 columns of pooled sera from five uremic dogs before (-) and during (----) cimetidine treatment. The arrows at the top of the graph indicate the elution positions of markers used to calibrate the columns. $\% \mathrm{~B} / \mathrm{F}$, bound-to-free hormone ratio of samples as a fraction of controls containing only tracer hormone. (A) Equal volumes of pooled concentrated sera were applied to the columns. (B) Equal amounts of immunoreactivity were applied to the columns. The similar elution profile excludes alterations in hormone metabolism as a cause for decreased total immunoreactivity.

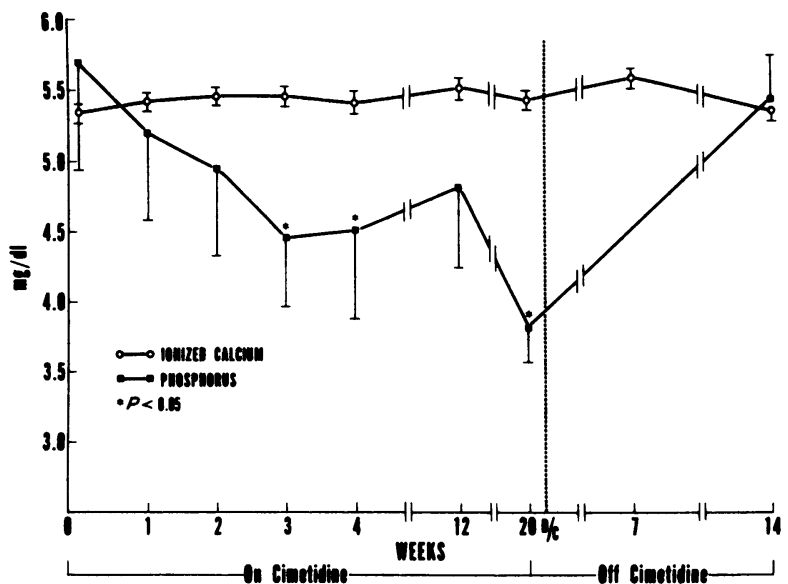

FIGURE 3 Change in serum ionized calcium and phosphorus concentration in five uremic dogs before, during, and after cimetidine treatment. Each point is the mean of three determinations made on five dogs. Individual serum phosphorus concentration during week 20 were: $1-2.9 \mathrm{mg} / \mathrm{dl}, 2-3.5$ $\mathrm{mg} / \mathrm{dl}, 3-4.1 \mathrm{mg} / \mathrm{dl}, 4-2.8 \mathrm{mg} / \mathrm{dl}$, and 5-3.6 mg/dl

sive decrease in serum phosphorus from $5.7 \pm 0.9 \mathrm{mg} / \mathrm{dl}$ during the control week to $4.5 \pm 0.5 \mathrm{mg} / \mathrm{dl}$ during the 3rd and 4th wk and $3.4 \pm 0.2 \mathrm{mg} / \mathrm{dl}$ by the 20 th wk of cimetidine therapy (all values $P<0.05$ ). 14 wk after withdrawal of cimetidine, serum phosphorus increased to $5.4 \pm 0.4 \mathrm{mg} / \mathrm{dl}(P<0.05)$, a value not significantly different from the pretreatment value.

Metabolic balance studies revealed that during cimetidine therapy calcium balance became positive (Table I). During the control week, the five dogs were in a negative calcium balance of $-367 \pm 120 \mathrm{mg} / 72 \mathrm{~h}$. Negative calcium balance is a consistent feature in chronically uremic man (16) and dogs (8) and is due to fecal calcium losses. 3 and 4 wk after initiation of cimetidine therapy, the mean change in calcium balance was $+550 \pm 259$ and $+674 \pm 334 \mathrm{mg} / 72 \mathrm{~h}$ (Fig. 4). These changes reached borderline significance

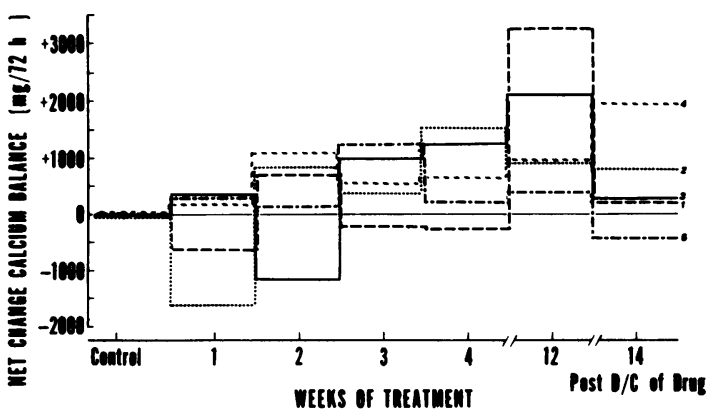

FIgURE 4 Net change in calcium balance in five uremic dogs during and after cimetidine therapy. Each dog is plotted individually and the numbers correspond to the dogs in Table I. 
$(0.05<P<0.1)$. During the 12 th wk of cimetidine, calcium balance was positive in all five dogs and increased by a mean of $1,509 \pm 518 \mathrm{mg} / 72 \mathrm{~h}(P<0.05)$. This was due to an increase in net intestinal calcium absorption from $-304 \pm 94 \mathrm{mg} / 72 \mathrm{~h}$ during the control week to $+1,180 \pm 419 \mathrm{mg} / 72 \mathrm{~h}$ during week $12(P<0.05)$. In contrast calcium balance was never positive in the two control dogs. There were no changes in phosphorus balance, creatinine clearance, and $24 \mathrm{~h}$ fractional phosphate excretion during the balance periods (Table I).

Changes in vitamin $\mathrm{D}$ metabolites may be related to alterations in calcium balance. Circulating concentrations of 25-hydroxycholecalciferol, 24,25-dihydroxycholecalciferol, and 1,25-dihydroxycholecalciferol were measured before and during cimetidine therapy. Serum 25(OH)D increased insignificantly from $31.2 \pm 7.6 \mathrm{ng} / \mathrm{ml}$ before therapy to $35.3 \pm 6.0 \mathrm{ng} / \mathrm{ml}$ after therapy. However, $1,25(\mathrm{OH})_{2} \mathrm{D}$ increased in all treated dogs by a mean of $55 \%$ from $33.4 \pm 4.3 \mathrm{pg} / \mathrm{ml}$ before therapy to $51.8 \pm 2.4 \mathrm{pg} / \mathrm{ml}$ after therapy ( $P$ $<0.01)$. 24,25 $(\mathrm{OH})_{2} \mathrm{D}$ decreased concomitantly from $2.4 \pm 0.3 \mathrm{ng} / \mathrm{ml}$ to $1.9 \pm 0.2 \mathrm{ng} / \mathrm{ml}(P<0.05)$ (Fig. 5).

Despite the decrease in iPTH, serum ionized calcium concentration could have been maintained if bone had increased its sensitivity to the remaining PTH. To examine this possibility, the calcemic response to exogenous PTH was examined in all seven dogs. The maximal increase in serum ionized calcium in the five treated dogs was $0.24 \pm 0.02 \mathrm{mg} / \mathrm{dl}$. This blunted response was not different from that seen in the two control uremic dogs in this study and eight uremic dogs with hyperparathyroidism previously reported from this laboratory (5) (Fig. 6).

\section{DISCUSSION}

Cimetidine was effective in decreasing circulating iPTH by $75 \%$ in our dogs with a remnant kidney and chronic renal insufficiency. Reduction of iPTH was evident despite the persistence of those factors that led to secondary hyperparathyroidism, i.e., a decrease in renal function and maintenance of a "normal" phos-
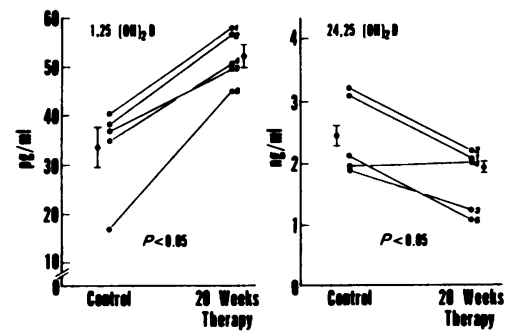

Figure 5 Serum concentration of $1,25(\mathrm{OH})_{2} \mathrm{D}$ and 24, $25(\mathrm{OH})_{2} \mathrm{D}$ before and during cimetidine treatment in five uremic dogs. Data are plotted for both the individual dogs and the mean \pm SEM. The numbers at each line correspond to the dogs in Table $I$.

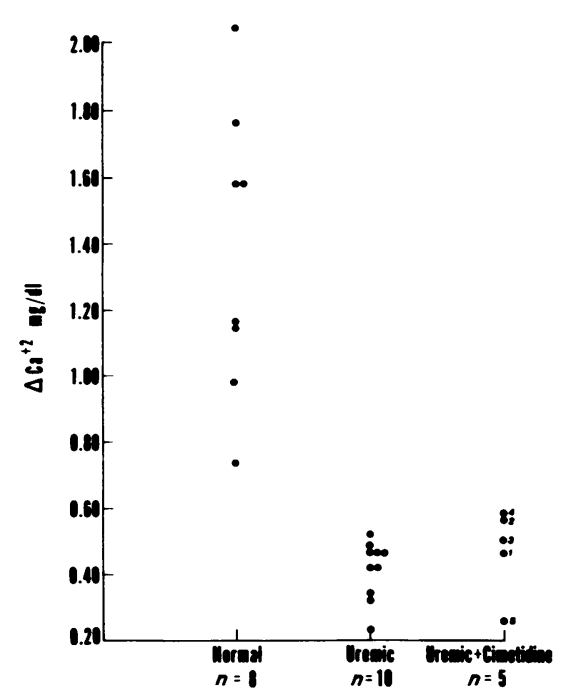

FIGURE 6 Maximal increase in serum ionized calcium after infusion of PTH (4 U/kg per h for $3 \mathrm{~h}$ ). The calcemia in five cimetidine-treated dogs is compared with the two control uremic dogs and an additional eight uremic and eight normal dogs described previously (5). The numbers at each point correspond to the dogs in Table $I$.

phate intake. Elevated concentrations of circulating iPTH have been previously demonstrated in chronically uremic man and $\operatorname{dog}(4,5,8,9,15,17,18)$. This elevation reflects both an increased rate of secretion of PTH and an accumulation of metabolites due to delayed excretion (19). Intact PTH is metabolized by the liver and kidney to lower molecular weight fragments that are excreted primarily by glomerular filtration $(1,20)$. In chronic renal disease, these metabolites accumulate and contribute to the elevation in serum iPTH. PTH immunoassays that measure $\mathrm{COOH}$-fragments are particularly sensitive to changes in peripheral metabolism (19). The decrease in iPTH during cimetidine therapy therefore could reflect either a change in secretory rate of hormone or an acceleration of peripheral metabolism. A comparison of the profile of immunoreactivity obtained after gel chromatography shows clearly that cimetidine did not affect the metabolism of PTH. Hence, cimetidine must have reduced the secretion of PTH by the parathyroids (10). An equally enhanced clearance of all species of iPTH by cimetidine is unlikely, as this would require an effect on liver, kidney, and bone, the organs involved in PTH metabolism.

Preliminary studies with parathyroid slices from normal bovine glands (21) and isolated dispersed cells from human adenomatous glands (22) have shown that histamine stimulates cAMP production and PTH release. These effects are blocked by cimetidine. Circulating iPTH in normal subjects acutely decreases with cimetidine infusion and returns to control levels when the infusion is terminated (21). Histamine may 
therefore play a role in normal parathyroid physiology and hyperparathyroid conditions. Stimulation of PTH secretion by hypocalcemia and $\beta$-agonists is felt to be secondary to activation of adenylate cyclase $(23,24)$. It is possible that the parathyroid gland adenylate cyclase may be histamine sensitive, a characteristic of cardiac (25) and gastric adenylate cyclase (26).

After withdrawal of cimetidine, iPTH values slowly increased, and only 20-30 wk later did iPTH return to pretreatment levels. Accumulation of cimetidine and its metabolites in chronic uremia may account for the delayed return of iPTH values after withdrawal. A single oral dose of cimetidine is excreted in the urine mostly unchanged and as a sulfoxide. However, substantial amounts of poorly characterized polar conjugates are also detected (27). Cimetidine excretion is depressed in renal failure (28), and accumulation of metabolites, if biologically active, could account for the slow return of iPTH values. There is no definite information concerning the biological activity and concentration of cimetidine metabolites in chronic renal failure.

Alternatively, the delayed recovery of iPTH values may reflect a slow return to the condition of secondary hyperparathyroidism. The stimuli that originally led to secondary HPTH remain operative after withdrawal of the drug. However, there may be a period of several weeks during which the parathyroid glands progressively increase their secretory rate and PTH fragments accumulate. In addition, if the reversal of secondary HPTH by cimetidine was associated with a decrease in functional gland mass, a lag period of glandular hypertrophy and hormone accumulation would be expected.

An elevated concentration of PTH may be necessary to maintain a normal serum calcium in chronic uremia (29). Therefore, a decrease in secretion of metabolically active PTH by cimetidine should have resulted in hypocalcemia. The two possible mechanisms that could have participated in maintaining eucalcemia are enhancement of gastrointestinal calcium absorption or an increase in bone calcium release. Sensitivity of bone to PTH is not enhanced in uremia but depressed (5). As shown in Fig. 6, cimetidine treatment did not modify the blunted calcium-mobilizing action of PTH on bone in these uremic animals. The most reasonable explanation for the lack of change of serum calcium despite decreased PTH secretion is that intestinal absorption of calcium was enhanced. Considerable variations in calcium intake occurred in both the control and treated dogs. A decrease in calcium intake would tend to mask positive effects on calcium balance. At week 12 , three of the five treated dogs had a calcium intake less than during the control week. Nonetheless, calcium balance was significantly positive, primarily due to an enhanced net gastrointestinal calcium absorption. A defect in intestinal calcium absorption is a consistent finding in chronic renal insufficiency $(8,16,30-32)$. Our dogs with creatinine clearances $\sim 15 \%$ of normal were not severely uremic but were in negative calcium balance despite a calcium intake of $>3 \mathrm{~g}$ daily. This defect has been attributed to a deficiency of $1,25(\mathrm{OH})_{2} \mathrm{D}$. Although the normal range of circulating $1,25(\mathrm{OH})_{2} \mathrm{D}$ levels in dogs offered a similar diet is unknown, our dogs were certainly not deficient in this metabolite as the mean concentration before cimetidine therapy was $33.4 \mathrm{pg} / \mathrm{ml}$, a value within the normal range for man. Cimetidine increased circulating levels of $1,25(\mathrm{OH})_{2} \mathrm{D}$ in all five dogs. This was associated with a concomitant fall in the concentration of $24,25(\mathrm{OH})_{2} \mathrm{D}$. The control of $1 \alpha$-hydroxylation by PTH (33), calcium (34) and phosphorus (35) has been described in various species. However, there are no data concerning modulation of metabolism of vitamin $D$ by these factors in renal disease. The changes in $\mathrm{D}$ metabolites may have been secondary to the decrease in serum phosphate concentration, an important modulator of renal $1 \alpha$ - and 24hydroxylase activities (35). Our studies suggest that $1,25(\mathrm{OH})_{2} \mathrm{D}$ levels will increase in dogs with renal insufficiency in response to a decrease in serum phosphorus. The increase in $1,25(\mathrm{OH})_{2} \mathrm{D}$ concentration probably accounts for the net positive calcium balance during cimetidine therapy. A possible role for phosphorus in peripheral $1,25(\mathrm{OH})_{2} \mathrm{D}$ metabolism has been postulated (36) and it is possible that metabolic degradation of $1,25(\mathrm{OH})_{2} \mathrm{D}$ was inhibited by the decrease in serum phosphorus. A direct suppressive effect of $1,25(\mathrm{OH})_{2} \mathrm{D}$ on PTH glandular secretion has been observed by some investigators (37). It is possible that cimetidine directly stimulated renal synthesis of $1,25(\mathrm{OH})_{2} \mathrm{D}$ thereby decreasing iPTH. However, the decrease in iPTH occurred much earlier than the changes in calcium balance, suggesting that the vitamin $D$ effect was a later and therefore secondary event.

The mechanisms responsible for the decrease in serum phosphorus concentration are unclear. Despite the increase in net gastrointestinal calcium absorption with cimetidine, phosphorus absorption remained unchanged. Coburn et al. (38) have shown that the administration of $1,25(\mathrm{OH})_{2} \mathrm{D}$ to chronically uremic patients will enhance net intestinal absorption of calcium and phosphorus to an equivalent degree. If the increase in $1,25(\mathrm{OH})_{2} \mathrm{D}$ concentration in our dogs is responsible for the changes in calcium balance, similar effects on phosphorus balance should have been observed. Nonetheless, the balance data clearly exclude decreased intestinal absorption or increase renal losses as contributing to the change in serum phosphorus. After 3 wk of cimetidine treatment, serum phosphorus had decreased significantly but net gastrointestinal absorption and urinary excretion of phosphorus varied inconsistently from the control week. These observations exclude primary changes in phosphorus balance as 
operative and evoke shifts of phosphorus within body compartments as a tenable explanation. The decreased concentration of iPTH after cimetidine may have caused less phosphorus to be lost from bone, thereby decreasing serum phosphorus. Alternatively, intracellular accumulation of phosphorus secondary to changes in vitamin $\mathrm{D}$ metabolites (39) or incorporation into phospholipids (40) may be responsible. The relative contribution of any of these possibilities is unknown. Despite the decrease in the serum and filtered load of phosphorus, renal phosphorus excretion was unchanged. This relative phosphaturia may have been secondary to the increase in $1,25(\mathrm{OH})_{2} \mathrm{D}$, as this agent will cause phosphaturia when administered chronically to thyroparathyroidectomized rats (41).

More than a decade ago, secondary HPTH was postulated to be directed at the maintenance of phosphate homeostasis in chronic uremia (15). Each decrement in gomerular filtration rate would be associated with transient hyperphosphatemia, hypocalcemia, and an increase in PTH secretion. Secondary HPTH would cause phosphaturia and restore phosphate balance thereby normalizing serum phosphate and calcium levels. As renal function deteriorates, phosphate balance would be maintained at the expense of increasingly severe HPTH. Although Swenson et al. (42) have shown that phosphate homeostasis may be maintained in parathyroidectomized uremic dogs given vitamin $D$, a direct effect of vitamin $D$ on renal phosphate handling in uremia was not excluded. Our data indicate that attenuation of HPTH does not impair phosphate homeostasis in uremic dogs. Although PTH is critical for phosphate homeostasis in chronic renal disease, our observations suggest that factors other than hyperparathyroidism may also be involved.

\section{ACKNOWLEDGMENTS}

The authors are grateful to Mr. Juan Sardinas for his assistance in caring for the dogs, Mrs. Lizabeth Hernandez and Mrs. Rosa Mari Alvarez for their secretarial assistance. Dr. Eric Reiss provided valuable commentary and assistance with the manuscript. Cimetidine tablets were the generous gift of Dr. R. Myerson, Smith Kline \& French Laboratories, Philadelphia, Pa.

This investigation was supported in part by National Institutes of Health grant AM19822, a grant from the State of Florida, and funds from Mr. and Mrs. R. Chambers.

\section{REFERENCES}

1. Slatopolsky, E., K. Martin, and K. Hruska. 1980. Parathyroid hormone metabolism and its potential as a uremic toxin. Am. J. Physiol. 239: F1-F12.

2. Massry, S. G., and D. A. Goldstein. 1979. The search for uremic toxin(s) "X", "X" = PTH. Clin. Nephrol. 11: $181-189$.

3. Clarkson, E. M., V. A. Luck, W. V. Hynson, R. R. Bailey, J. B. Eastwood, J. S. Woohead, V. R. Clements, J. L. H. O'Riordan, and H. E. DeWardener. 1972. The effect of aluminum hydroxide on calcium, phosphorus and aluminum balances, serum parathyroid hormone concentration and the aluminum content of bone in patients with chronic renal failure. Clin. Sci. (Oxf.) 43: 519-531.

4. Slatopolsky, E., S. Caglar, L. Gradowska, J. M. Canterbury, E. Reiss, and N. S. Bricker. 1972. On the prevention of secondary hyperparathyroidism in experimental chronic renal disease using proportional reduction of dietary phosphorus intake. Kidney Int. 2: 147-151.

5. Kaplan, M. A., J. M. Canterbury, G. Gavellas, D. Jaffe, J. J. Bourgoignie, E. Reiss, and N. S. Bricker. 1978. The calcemic and phosphaturic effects of parathyroid hormone in the nornal and uremic dog. Metab. Clin. Exp. 27: 1785-1791.

6. Jacob, A. I., D. Lanier, J. M. Canterbury, and J. J. Bourgoignie. 1980. Cimetidine suppression of circulating parathyroid hormone in uremia. N. Engl. J. Med. 302: 671-674.

7. Schultz, R., H. Shapiro, and N. S. Bricker. 1969. Studies on the control of sodium excretion in experimental uremia. J. Clin. Invest. 48: 869-877.

8. Canterbury, J. M., G. Gavellas, J. J. Bourgoignie, and E. Reiss. 1980. Metabolic consequences of oral administration of 24,25-dihydroxycholecalciferol to uremic dogs. J. Clin. Invest. 65: 571-576.

9. Canterbury, J. M., A. Lerman, A. Claflin, H. Henry, A. Norman, and E. Reiss. 1978. Inhibition of parathyroid hormone secretion by 25-hydroxycholecalciferol and 24,25-dihydroxycholecalciferol in the dog. J. Clin. Invest. 61: $1375-1383$.

10. Canterbury, J. M., and E. Reiss. 1972. Multiple immunoreactive molecular forms of parathyroid hormone in human serum. Proc. Soc. Exp. Biol. Med. 140: 1393-1398.

11. Canterbury, J. M., L. A. Bricker, G. S. Levey, P. L. Kozlovskis, E. Ruiz, J. E. Zull, and E. Reiss. 1975. Metabolism of bovine parathyroid hormone: immunological and biological characteristics of fragments generated by liver perfusion. J. Clin. Invest. 55: 1245-1253.

12. Lambert, P. W., B. J. Syverson, C. D. Arnaud, and T. C. Spelsberg. 1977. Isolation and quantitation of endogenous vitamin $\mathrm{D}$ and its physiologically important metabolites in human plasma by high performance liquid chromatography. J. Steroid Biochem. 8: 929-937.

13. Lambert, P. W., D. A. Toft, S. F. Hodgson, E. A. Lindmark, B. J. Witwach, and B. A. Roos. 1979. An improved method for the measurement of $1,25(\mathrm{OH})_{2} \mathrm{D}$ in human plasma. Endocr. Res. Commun. 5: 293-310.

14. Kaplan, M. A., J. M. Canterbury, G. Gavellas, D. Jaffe, J. J. Bourgoignie, E. Reiss, and N. S. Bricker. 1978. Interrelations between phosphorus, calcium, parathyroid hormone, and renal phosphate excretion in response to an oral phosphorus load in normal and uremic dogs. Kidney Int. 14: 207-214.

15. Slatopolsky, E., S. Caglar, J. P. Pennell, D. D. Taggart, J. M. Canterbury, E. Reiss, and N. S. Bricker. 1971. On the pathogenesis of hyperparathyroidism in chronic experimental renal insufficiency in the dog. J. Clin. Invest. 50: $492-499$.

16. Liu, S. H., and H. I. Chu. 1943. Studies of calcium and phosphorus metabolism with special reference to the pathogenesis and effect of dihydrotachysterol (AT 10) and iron. Medicine (Baltimore). 22: 103-161.

17. Reiss, E., J. M. Canterbury, and A. Kantor. 1969. Circulating parathyroid hormone concentration in chronic renal insufficiency. Arch. Intern. Med. 124: 417-422.

18. Arnaud, C. D. 1973. Hyperparathyroidism and renal failure. Kidney Int. 4: 89-95.

19. Freitag, J. K., K. J. Martin, K. A. Hruska, C. Anderson, M. 
Conrades, J. Landenson, S. Klahr, and E. Slatopolsky. 1978. Impaired parathyroid hormone metabolism in patients with chronic renal failure. N. Engl. J. Med. 298: 29-32.

20. Martin, K. J., K. A. Hruska, J. J. Freitag, S. Klahr, and E. Slatopolsky. 1979. The peripheral metabolism of parathyroid hormone. N. Engl. J. Med. 301: 1092-1098.

21. Williams, G. A., R. S. Longley, G. K. Hargis, E. N. Bowser, S. C. Kukreja, P. A. Johnson, B. L. Jackson, and W. J. Kawahora. 1979. Effect of histamine on secretion of parathyroid hormone. Clin. Res. 27: 704A. (Abstr.)

22. Brown, E. M. 1980 . Histamine receptors in parathyroid adenomas. Clin. Res. 28: 388A (Abstr.).

23. Abe, M., and L. M. Sherwood. 1972. Regulation of parathyroid hormone secretion by adenyl cyclase. Biochem. Biophys. Res. Commun. 48: 396-401.

24. Brown, E. M., D. G. Gardner, R. A. Windick, and G. D. Aurbach. 1978. Relationship of intracellular $3^{\prime}, 5^{\prime}$ adenosine monophosphate accumulation to parathyroid hormone release from dispersed bovine parathyroid cells. Endocrinology. 103: 2323-2333.

25. Levey, G. S., and I. Klein. 1972. Solubilized myocardial adenylate cyclase. Restoration and histamine responsiveness by phosphatidylserine. J. Clin. Invest. 51: 15781582.

26. Dousa, T. P., and C. T. Code. 1974. Effect of histamine and its methyl derivatives on cyclic AMP metabolism in gastric mucosa and its blockade by an $\mathbf{H}_{2}$-receptor antagonist. J. Clin. Invest. 53: 334-337.

27. Griffiths, R., R. M. Lee, and D. C. Taylor. 1977. Kinetics of cimetidine in man and experimental animals. In Proceedings of the Second International Symposium on Histamine $\mathrm{H}_{2}$ Receptor Antagonists. Excerpta Medica, Amsterdam. 38-51.

28. Canavan, J. S. F., and J. D. Briggs. 1977. Cimetidine clearance in renal failure. In Proceedings of the Second International Symposium on Histamine $\mathbf{H}_{2}$ Receptor Antagonists. Excerpta Medica, Amsterdam. 75-80.

29. Avioli, L. V., S. Birge, and E. Slatopolsky. 1969. The nature of vitamin $D$ resistance of patients with chronic renal disease. Arch. Intern. Med. 124: 451-460.

30. Stanbury, S. W., and G. A. Lumb. 1962. Metabolic studies in renal osteodystrophy, I. Calcium, phosphorus and nitrogen metabolism in rickets, osteomalacia and hyperparathyroidism complicating chronic uremia and in the osteomalacia of the adult Fanconi syndrome. Medicine (Baltimore). 41: 1-31.

31. Coburn, J. W., M. H. Koppel, A. S. Brinkman, and S. G. Massry. 1973. Study of intestinal absorption of calcium in patients with renal failure. Kidney Int. 3: 264-272.

32. Schiffl, H., and U. Binswanger. 1980. Calcium ATPase and intestinal calcium transport in uremic rats. Am. J. Physiol. 238: G424-G428.

33. Henry, H. L., R. J. Midgett, and A. W. Norman. 1979. Regulation of 25-hydroxyvitamin D3-l $\alpha$-hydroxylase in vivo. J. Biol. Chem. 249: 7584-7592.

34. Boyle, I. T., R. W. Gray, and H. F. DeLuca. 1971. Regulation by calcium of in vivo synthesis of 1,25-hydroxycholecalciferol and 21,25-dihydroxycholecalciferol. Proc. Natl. Acad. Sci. U. S. A. 68: 2131-2134.

35. Tanaka, Y., and H. F. DeLuca. 1973. The control of 25-hydroxyvitamin D metabolism by inorganic phosphorus. Arch. Biochem. Biophys. 145: 566-574.

36. Ribovich, M. L., and H. F. DeLuca. 1978. Effect of dietary calcium and phosphorus on intestinal calcium absorption and vitamin D metabolism. Arch. Biochem. Biophys. 188: 145-156.

37. Chertow, B. S., D. J. Baylink, J. E. Wergedal, M. H. H. Su, and A. W. Norman. 1975. Decrease in serum immunoreactive parathyroid hormone and parathyroid hormone secretion in vitro by 1,25-dihydroxycholecalciferol. J. Clin. Invest. 56: 668-678.

38. Coburn, J., A. S. Brickman, D. L. Hartenbower, and A. W. Norman. 1977. Intestinal phosphate absorption in normal and uremic man: effects of $1,25(\mathrm{OH})_{2}$-vitamin $\mathrm{D}_{3}$ and $1 \alpha(\mathrm{OH})$-vitamin $\mathrm{D}_{3}$. Adv. Exp. Biol. Med. 81: 549-557.

39. Birge, S. J., and J. G. Haddad. 1975. 25-Hydroxycholecalciferol stimulation of muscle metabolism. J. Clin. Invest. 56: 1100-1107.

40. Thompson, V., and H. F. DeLuca. 1963. Vitamin D and phospholipid metabolism. J. Biol. Chem. 239: 984-990, 1963.

41. Bonjour, J-P., C. Preston, and H. Fleisch. 1977. Effect of 1,25-dihydroxyvitamin $D_{3}$ on the renal handling of $P_{1}$ in thyroparathyroidectomized rats. J. Clin. Invest. 60: 1419-1428.

42. Swenson, R. S., J. R. Weisinger, J. L. Ruggeri, and G. M. Reaven. 1975. Evidence that parathyroid hormone is not required for phosphate homeostasis in renal failure. Metab. Clin. Exp. 24: 199-209. 